\title{
Desain Sistem Pembangkit Lisrik Tenaga Surya Pada Tambak Udang sebagai Penggerak Aerator
}

\author{
Ahmad Rosyid Idris ${ }^{1, a}$ dan Sarma Thaha ${ }^{1, b}$ \\ ${ }^{1}$ Teknik Elektro, Politeknik Negeri Ujung Pandang, Jln. Perintis Kemerdakaan, Tamalanrea, Makassar \\ a Ahmadrosyid.idris@gmail.com \\ b Sarmathaha@gmail.com
}

\begin{abstract}
Indonesia is a tropical region with very large solar energy where an average daily insulation of $4.5-4.8 \mathrm{KWh} / \mathrm{m}^{2}$ / day. Based on this fact, solar energy is a potential form of renewable energy to be developed. This study aims to design a PLTS system which is the initial stage of planning PLTS system development. This system Design uses Matlab software by utilizing the Matrix Unit Interface (GUI) Matlab to calculate the amount of electrical load to be used, battery capacity requirements, number of solar modules and large capacity of the inverter to be used. Location of the measurement data collection takes place in the city of Pinrang, area of the Suppa sub-district shrimp farm. Measurements are conducted to determine how much solar radiation and air temperature in the pond area.
\end{abstract}

Keywords-- PLTS; GUI; solar energy

Abstrak - Indonesia merupakan daerah tropis yang memiliki energi energi surya sangat besar dengan insolasi harian rata-rata 4,5 - 4,8 KWh / $\mathrm{m}^{2}$ / hari. Berdasarkan hal ini maka energi surya menjadi salah satu bentuk energi terbarukan yang potensial untuk dikembangkan. Penelitian ini bertujuan untuk mendesain sistem PLTS yang merupakan tahap awal dari perncanaan pembangunan sistem PLTS. Sistem ini di desain meggunakan software Matlab dengan memanfaat antarmuka unit Graphics (GUI) Matlab untuk menghitung besarnya beban listrik yang akan digunakan, kebutuhan kapasitas baterai, jumlah modul surya dan besar kapasitas inverter yang akan di gunakan. Lokasi Pengambilan data pengukuran ini bertempat di kota Pinrang di daerah tambak udang Kecamatan Suppa. pengukuran dilakukan untuk mengetahui seberapa besar radiasi matahari dan temperatur udara di daerah tambak.

Kata Kunci-PLTS; GUI; energy matahari

\section{Pendahuluan}

Sumber energi baru dan yang terbarukan di masa mendatang akan semakin mempunyai peran yang sangat penting dalam memenuhi kebutuhan energi. Hal ini disebabkan oleh penggunaan bahan bakar fosil untuk pembangkit - pembangkit listrik konvesional dalam jangka waktu yang panjang akan menguras sumber minyak bumi, gas dan batu bara yang cadangannya semakin lama semakin menipis [1].

PLTS atau lebih dikenal dengan sel surya (Photovoltaic Cell) akan lebih diminati karena dapat digunakan untuk berbagai keperluan yang relevan dan diberbagai tempat seperti perkantoran, pabrik, perumahan, dan lainnya. Sehingga hal ini dipandang perlu untuk dikaji lebih lanjut, agar diperoleh kajian yang komprehensif secara teknik [2], [3].

Disain sistem pembangkit Listrik Tenaga Surya (PLTS) akan sangat bergantung pada berbagai macam parameter, seperti misalnya kondisi lokasi, besarnya radiasi dan temperatur lingkungan, pemilihan komponen, yang terdiri dari jenis modul surya, baterai, sistem kontrol, inverter dan komponen pendukung lainnya [4]. Tahapan mendesain sistem PLTS, dilakukan dalam dua tahap, pertama adalah mendesain konsep atau rancangan dasar dari data-data hasil studi kelayakan, kemudian yang kedua adalah detail desain engineering [5], yang dilakukan dengan menggunakan perangkat lunak yang ada di pasar seperti misalnya Hommer, PV Syst, ETAP dan lain-lain.

Tahapan mendesain sistem PLTS juga akan tergantung dari jenis sistem PLTS, yaitu sistem PLTS off-grid (tidak terhubung dengan jala-jala) dan sistem PLTS on-grid (sistem terhubung dengan jala-jala). Untuk penelitian ini sistem PLTS yang digunakan adalah PLTS off-grid sehingga harus dihitung kapasitas beban yang akan di tanggung oleh PLTS itu sendiri. 
Kemudian dilakukan perhitungan kapasitas kompone PLTS itu sendiri.

\section{A. Perhitungan Kapasitas Komponen PLTS}

Daya (wattpeak) yang dibangkitkan PLTS untuk memenuhi kebutuhan energi, diperhitungkan dengan persamaan-persamaan sebagai berikut [6]:

\section{Menghitung Area Array (PV Area)}

Area array (PV Area) diperhitungkan dengan menggunakan rumus sebagai berikut:

PV Area $=E L /$ Gav $\times$ TCF $\times \eta P V \times$ pout

Dimana:

EL = Energi yang dibangkitkan $(\mathrm{kWh} / \mathrm{hari})$

PV Area $=$ Luas permukaan panel surya $(\mathrm{m} 2)$

Gav = Intensitas Matahari harian $(\mathrm{kW} / \mathrm{m} 2 /$ hari $)$

$\mathrm{TCF}=$ Temperature coefficient faktor $(\%)$

$\eta \mathrm{PV} \quad=$ Efisiensi panel surya $(\%)$

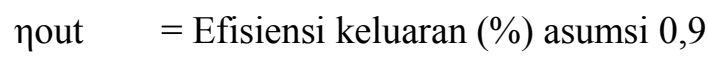

\section{Menghitung Daya yang Dibangkitkan PLTS}

Dari perhitungan area array, maka besar daya yang dibangkitkan PLTS (wattpeak) dapat diperhitungkan dengan rumus sebagai berikut:

Pwatt $p e a k=$ PV Area $x$ PSI $x \eta P V($ watt $)$

\section{Dimana:}

PV Area $=$ Luas permukaan panel surya $(\mathrm{m} 2)$

PSI $=$ Peak Solar Insolation adalah $1.000 \mathrm{~W} / \mathrm{m} 2$

$\eta \mathrm{PV}=$ Efisiensi panel surya $(\%)$

Selanjutnya berdasarkan besar daya yang akan dibangkitkan (wattpeak), maka jumlah panel surya yang diperlukan, diperhitungkan dengan rumus sebagai berikut:

Jumlah panel surya $=$ Pwatt peak $/$ PMPP

Dimana:

Pwatt peak = Daya yang dibangkitkan (WP)
PMPP = Daya maksimum keluaran panel surya (watt)

\section{Kapasitas Controller}

Kapasitas Charge controller ditentukan dengan rumus sebagai berikut:

Capacity SCC $=($ Demand watt $x$ Safety Faktor $) /($ System Voltage) (ampere)

Dimana safety faktor (faktor keamanan) ditentukan sebesar 1,25 .

\section{Kapasitas Inverter}

Kapasitas inverter ditentukan dengan rumus sebagai berikut:

Cap.Inv $=$ Demand watt $\mathrm{x}$ Safety Faktor

\section{Kapasitas Baterai}

Besar kapasitas baterai yang dibutuhkan untuk memenuhi konsumsi energi harian dapat dihitung dengan rumus sebagai berikut:

$$
\mathrm{C}=\mathrm{N} \times \mathrm{Ed} \text { VSx DOD } \times \eta(\mathrm{Ah})
$$

\section{Dimana:}

$\mathrm{C}=$ Kapasitas baterai (Ampere-hour)

$\mathrm{N}=$ Jumlah hari otonomi (hari)

$\mathrm{Ed}=$ Konsumsi energi harian $(\mathrm{kWh})$

VS $=$ Tegangan baterai (Volt)

DOD $=$ Kedalaman maksimum untuk pengosongan baterai $(\%)$

$\eta=$ Efisiensi baterai $x$ efisiensi inverter

\section{GUIDE Matlab}

GUIDE atau GUI builder merupakan sebuah Graphical User Interface (GUI) yang dibangun dengan obyek grafik seperti tombol (button), kotak teks, slider, menu dan lain-lain. Aplikasi yang menggunakan GUI umumnya lebih mudah dipelajari dan digunakan karena orang yang menjalankannya tidak perlu mengetahui perintah yang ada dan bagaimana kerjanya [7].

Sampai saat ini, jika kita membicarakan pemrograman berorientasi visual, yang ada di benak kita adalah sederetan bahasa pemrograman, seperti visual basic, Delphi, visual $\mathrm{C}++$, visual Fox Pro, dan lainnya yang memang didesai secara khusus untuk itu. Matlab merintis ke arah pemrograman 
yang menggunakan GUI dimulai dari versi 5, yang terus disempurnkan sampai sekarang.

\section{Metode Penelitian}

Dalam penelitian ini metode analisis data yang digunakan adalah analisis deskriptif dengan perhitungan berdasarkan teori dan menggunakan software GUIDE Matlab. Gambar 1 menunjukkan prosedur kerja penelitian.

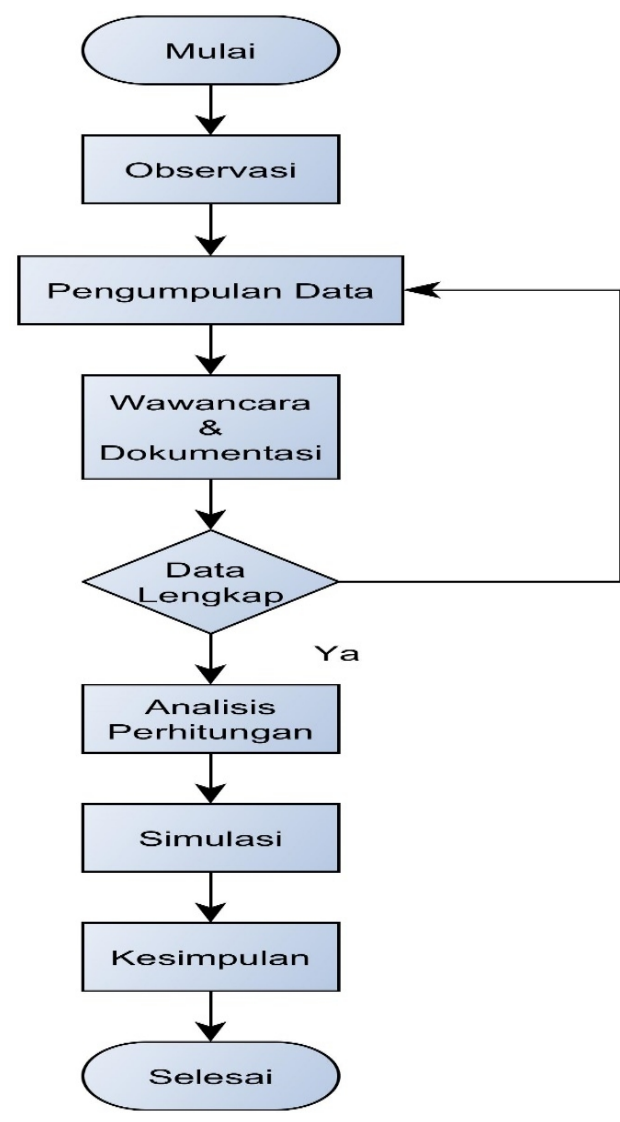

Gambar 1. Diagram Alir Penelitian

\section{Hasil dan Pembahasan}

Data hasil Penelitian adalah jenis beban yang akan ditanggung oleh PLTS antara lain:

1. Motor penggerak kincir

Motor penggerak kincir yang akan digunakan adalah Brushless DC electric motor (BLDC

Tidak motors, BL motors) dikenal juga sebagai electronically commutated motors (ECMs, EC motors), atau motor DC sinkron. Adapaun kapasitas motor yang digunakan adalah $500 \mathrm{~W} 48$ Volt yang digunakan selama 13 jam.

2. Penerangan jalan tambak

Lampu penerangan jalan tambak menggunakan lampu LED dengan kapasitas 24 Watt. Lampu yang digunakan sebanyak 5 buah. Untuk penerangan jalan dari rumah tambak menuju tambak yang digunakan selama 13 jam.

3. Penerangan Jumlah Tambak

Lampu pada penerangan rumah tambak menggunakan lampu DC $20 \mathrm{~W}$ sebanyak 4 buah yang di gunakan untuk penerangan rumah tambak yang digunakan selama 6 jam

Untuk perhitungan total beban dan kapasitas komponen modul surya menggunakan software simulasi yang telah dibuat dengan menggunakan GUI Matlab.

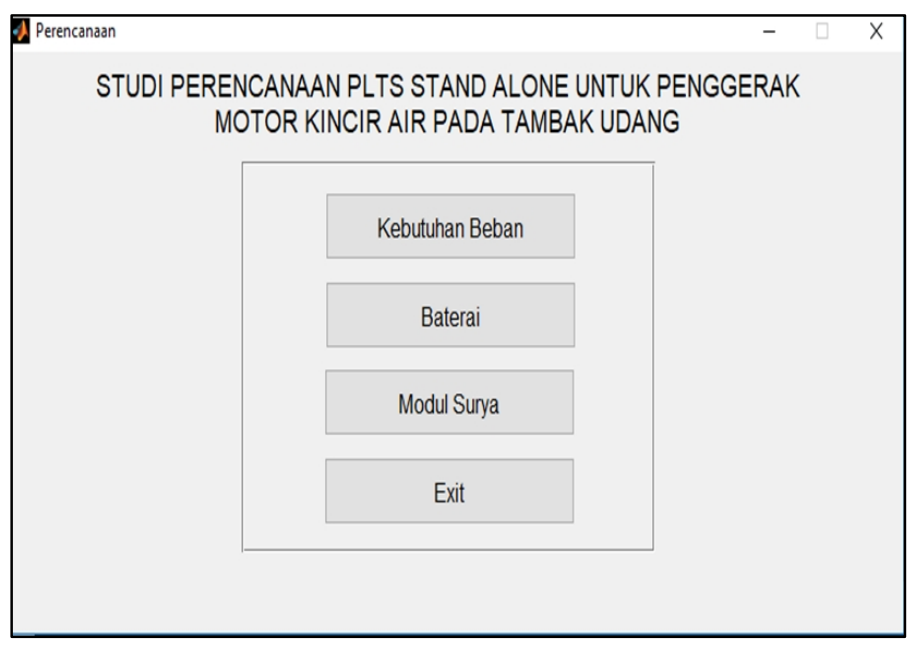

Gambar 2. Tampilan Awal Simulasi

Gambar 2 adalah tampilan bagian awal simulasi, pada tampilan awal simulasi dapat dipilih perhitungan kebutuhan beban, kapasitas baterai dan jumlah modul surya yang akan digunakan

Berdasarkan data yang diperoleh maka dapat dihitung berapa besar kebutuhan beban untuk memutar kincir dan penerangan pada tambak udang seperti terlihat pada gambar 3 . 


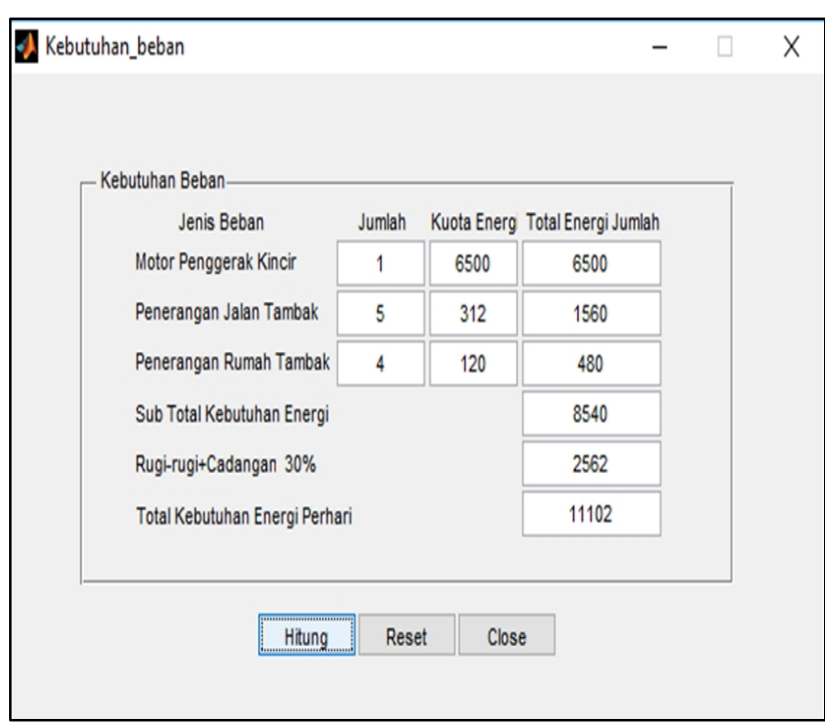

Gambar 3. Hasil Simulasi Kebutuhan Beban Harian

Dari hasil perhitungan pada simulasi diatas maka diperoleh total kebutuhan energi perhari sebesar 11102 Watt.

Berdasarkan total kebutuhan energi perhari selanjutya dilakukan perhitungan jumlah dan kapasitas battery serta jumlah modul surya yang di butuhkan. Adapun hasil simulasinya dapat dilihat pada gambar 4 dan gambar 5 .

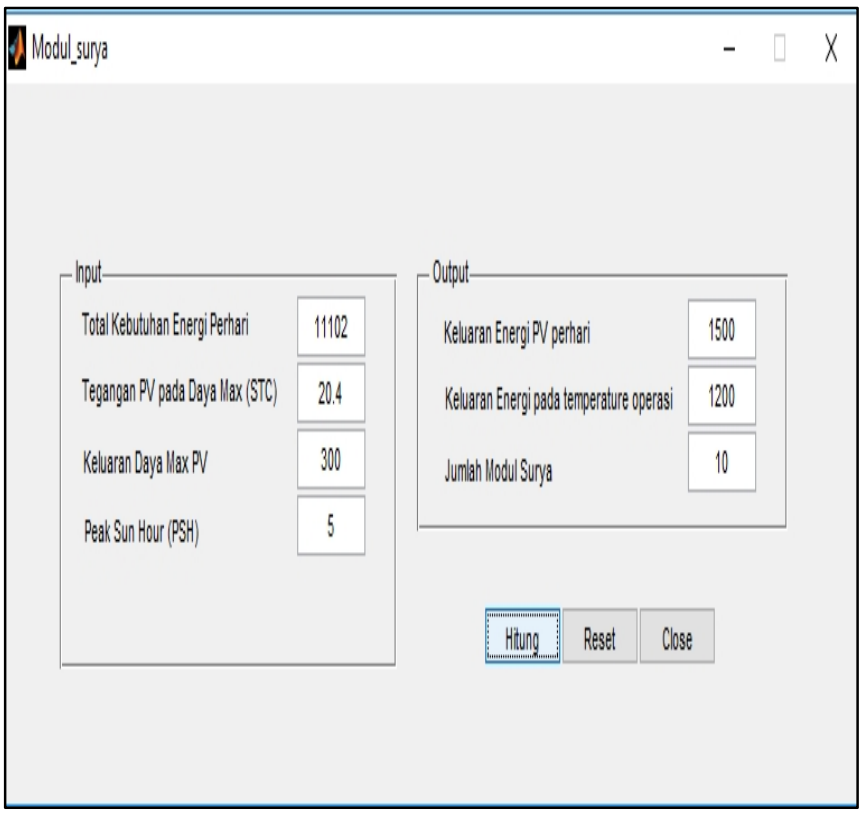

Gambar 4. Hasil Simulasi Perhutingan Modul Surya

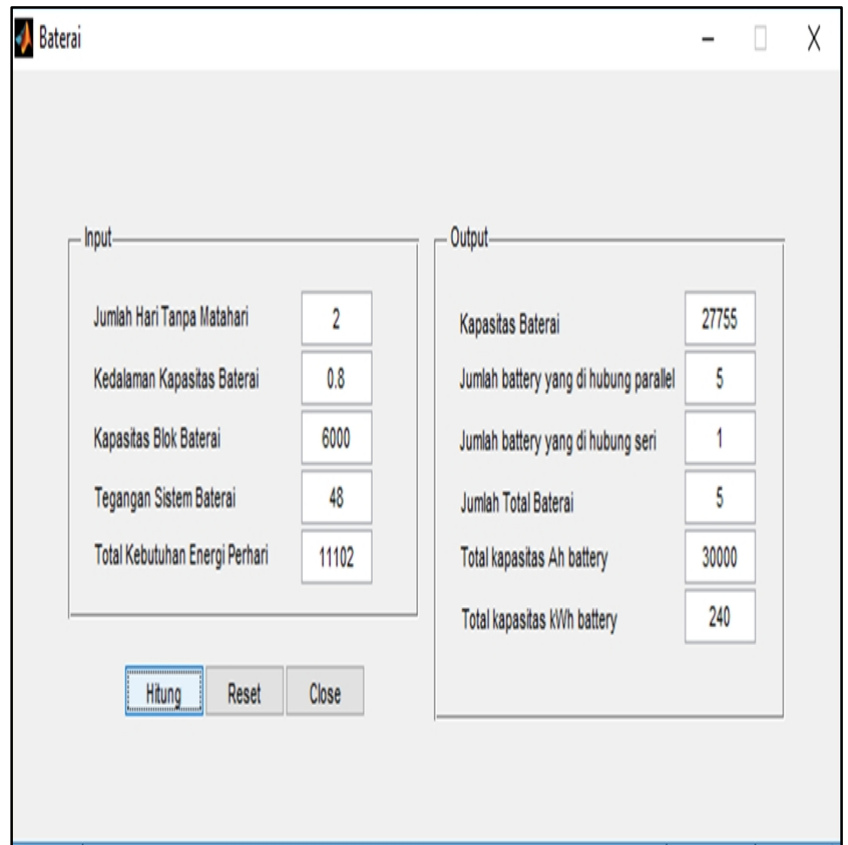

Gambar 5. Hasil simulasi Kebutuhan Battery

Berdasarkan hasil simulasi program diperoleh jumlah battery yang dibutuhkan adalah 5 buah dengan kapasitas $240 \mathrm{AH}$ serta jumlah modul surya sebanyak 10 buah dengan kapasitas masing-masing panel 300 Wp.

\section{Kesimpulan}

Berdasarkan hasil penelitian diperoleh kesimpulan sebagai berikut:

1. Untuk mendesain sistem PLTS pada tambak udang sebagai penggerak aerator tambak diperoleh total kebutuhan beban harian sebesar 11102 Watt yang terdiri dari 3 buah beban yaitu motor DC sebagai penggerak kincir, penerangan lampu jalan tambak dan penerangan rumah tambak.

2. Untuk menanggung beban harian tersebut dibutuhkan 5 buah battery dengan kapasitas 240 AH dan modul surya sebanyak 10 buah dengan kapasitas $300 \mathrm{Wp}$ masing-masing modul. 


\section{Ucapan Terima Kasih}

Ucapan terima kasih diberikan kepada kordinator petambak udang di Kabupaten Pinrang yang telah banyak memberikan kontribusi positif bagi penyelesaian penelitian ini termasuk memberikan tempat tinggal bagi peneliti pada saat pengambilan data.

\section{Daftar Pustaka}

[1] Anggara, I.W.G.A, Kumara, I.N.S., Giriantari, I.A.D, (2014), Studi Terhadap Unjuk Kerja Pembangkit Listrik Tenaga Surya 1,9 Kw Di Universitas Udayana Bukit Jimbaran, Spektrum, 1(1): $118-122$.

[2] Ubaidillah, Suyitno, Juwana, Wibawa Endra, (2012), Pengembangan Piranti Hibrid Termoelektrik - Sel Surya Sebagai Pembangkit Listrik Rumah Tangga, Jurnal Litbang Provinsi Jawa Tengah, 10(2): 194-21.

[3] Akhmad, Kholid, (2011), Pembangkit Listrik Tenaga Surya dan Penerapannya Untuk Daerah Terpencil, Jurnal Dinamika Rekayasa, 1(1): 28-33.

[4] M. Mulyadi, A. M. S. Yunus (2018), Motor BLDC Aerator Sistem Hibrid, Seminar Nasional Hasil Penelitian (SNP2M), Makassar.

[5] M. Mulyadi, A. M. S. Yunus (2018), Pengembangan Desain Aerator Terapung Sistem Panel Surya, Seminar Nasional Hasil Penelitian (SNP2M), Makassar.

[6] Eriyanto. (2017). Evaluasi Pemanfaatan PLTS Terpusat Siding Kabupaten Bengkayang. Jurnal ELKHA Vol. 9, No 1, 35-37.

[7] Wijaya, Riki Chandra, Modul GUI Matlab, Universitas Jambi. 